\title{
Exploring the Impact of Industrial Marketing Strategy from Asymmetric Thinking in Data Analysis
}

\author{
Cheng-Feng Cheng ${ }^{1}$, Li-Chuan Hsieh ${ }^{2}$
}

Department of International Business, Asia University

\begin{abstract}
This study attempts to evaluate the impact of industrial marketing strategy from the innovative cooperative manufacturer's perspectives and buyers' perspectives. In a highly competitive environment, marketing strategic management is one weapon for many firms to survive in the marketplace. Valuable strategic marketing enable a firm to obtain a dominant position and gain higher profits. Therefore, this study attempts to develop a theoretical model based on qualitative research to explore the strategic industrial marketing deal with overt cost per utility, information searching cost, moral hazard cost, and asset specificity cost. In order to examine the applicability of the proposed theoretical model, this study further conducts a quantitative research based on the qualitative research and will collect primary data from customers of cooperative manufacturer. The statistical techniques adopt contain descriptive statistics and qualitative comparative analysis using fuzzy sets (fs QCA).Based on the empirical analyses, this study attempts to derive several contributions. First of all, identify the major factors or causal conditions of high customer loyalty. Secondary, causal conditions of high customer loyalty support that the states causal combinations of high customer loyalty.
\end{abstract}

\section{INTRODUCTION}

With the trends of global economy recovery in recent years, the Ministry of Economic Affairs (2014) reported that, according the publication of Global Insight, the global economic growth rate in 2015 was expected to $3.0 \%$ (higher than the 2.7\% rate in 2014) and that in Asia and the Asia-Pacific region (exclusive of Japan) was expected to 5.6\%. In addition, the International Monetary Fund predicts that the global economy growth rate was 3.5\% in 2015(higher than the 3.3\% rate in 2014.) as well as the Directorate-General of Budget, Accounting and Statistics of Executive Yuan predicts that the domestic economy growth rate was $3.5 \%$ in 2015 (higher than the $3.43 \%$ rate in 2014) and an increase of $7.33 \%$ in industrial production in December of 2014. All the statistical data shows the stable growth in global and domestic economy. However, the industrial production can be viewed as the main factor for promoting economy recovery. Among the industrial development, machine tool is a core industry.

The export value of machinery equipments was approximately USD $\$ 14,333,000,000$ from January to August in 2014(increased 7.7\% compared to 2013) and the gross export value of machine tool was approximately USD $\$ 2,474,940,000$ (increased $5.2 \%$ compared to 2013). Base on the research results, the development of industry plays a key role in economy growth, especially in the machine tool industry, which is also an important research issue. Therefore, this study aims to facilitate the cooperative manufacturer (Jia-In Industry Co., Ltd.) whose major production is machine tools to develop the industrial marketing strategy from the point of view of the concept of strategic management and process and strengthening the company's competitive position and the possibility of creating profits. For the marketing strategy, some studies in the past focused on the analysis of 4Ps marketing mixes, which were Product, Price, Promotion, and Place (e.g., Goyal-Wasan \& Tripathi, 2014; Hansses et al., 2014; Helm \& Gritsch, 2014; Huang \& Sarigöllü, 2012; Noori, 2015). GoyalWasan \& Tripathi (2014) expanded the 4Ps concept to add some factors of Partnerships, Policy, and Publics to analyze the social marketing mix. Helm \& Gritsch (2014) used the 4Ps marketing as a tool to discuss the uncertainty of marketing effectiveness relating to the international trade of $\mathrm{B} 2 \mathrm{~B}$ (Business to business).

Further, Huang \& Sarigöllü (2012) analyzed the correlation between the brand recognition and the equality by means of the marketing mix of product, price, advertisement, and place. However, Chiu (2014) thought that the explanation of marketing activity of school of marketing management was on 
the basis of the structure of 4Ps. The said marketing mix was regarded as a main tool to solve the exchanging problems of four items, but four items of main cost still exist obstruction of exchange: Overt cost per utility (C1), Information searching cost(C2), Moral hazard cost (C3), and Asset specificity cost $(\mathrm{C} 4)$. Accordingly, the strategic marketing $4 \mathrm{C}$ framework for analysis was built up. Therefore, this study focuses on the cooperative manufacturer's strategic marketing $4 \mathrm{C}$ framework for analysis for making suggestions. The competitive environment of industry is facing the rapid change, so that the trend of developing marketing strategy becomes more popular according to the consumer orientation or the market orientation.

Especially in B2B (Business to business) market, it has a feature of few buyers but large amount of purchase (Armstrong\& Kotler, 2014), so that the analysis of customer satisfaction and loyalty have become a significant part of issue of the related research of B2B marketing territory and practical management. (e.g., Chou \& Lu, 2009; García \& Caro, 2009; Wang \& Wu, 2012; Yaghobi, Ahmadi, \& Shojaee, 2014) Generally, customers' loyalty can be regarded as a main resource for business's longterm profitability and competitive advantage (García \& Caro, 2009). Prentice (2013) emphasized on that the core of marketing strategy was built on the development and maintenance of customers' loyalty for business as well as the customer's faithful attitudes. Yaghobi et al. (2014) also considered that specific promotion and maintenance of customers' loyalty were both key factors for business making great profit in long-term period. In light of the above discussion, the effect of customers' loyalty will need to be considered while taking the $4 \mathrm{C}$ - framework marketing strategy as a tool for cooperative manufacturers.

According to the research background, the industrial development has been a key element for promoting economy growth-up, and the machine tool industry has become a core and indispensable business. Thus, this study takes Jia-In Industry Co., Ltd., the cooperative manufacturer, as a research object who produces some machineries such as automotive packing equipments and its materials. Jia-In Industry Co., Ltd. was established in 1973 and dedicated to manufacture various auto-strapping machine, carton stapler and pallet wrapping machines. The total capital of this company is NTD36,000,000 and 113 employees work in this company. The annual revenue of this company was approximately NTD300,000,000 and the enterprise group was around NTD120,000,000 in 2014. Moreover, Jia-In is famous for and typical of machine tool industry. Nevertheless, the cooperative manufacturer and tool machine industry concern how to enhance the marketing exchange efficiency, which is an important issue.

As to the above issue, Chiu (2014) established the 4C framework with the concepts of explicit cost and implicit cost, and specified that the perspectives of overt cost per unit, information searching cost, moral hazard cost, and asset specificity cost have always been main factors for buyers purchasing or getting services. In other words, the focus of the cooperative manufacturers for their marketing strategy is how to effectively reduce the explicit cost (overt cost per unit) or implicit cost (information searching cost, moral hazard cost, and asset specificity cost) and raise the effectiveness of marketing exchange. Therefore, this study is based on the view of strategic management and to discuss the suggestion of marketing strategies for the cooperative manufacturers. Following the trend of customer orientation or market orientation (e.g., Chou \& Lu, 2009; García \& Caro, 2009; Wang \& Wu, 2012; Yaghobi et al., 2014), the analysis of customer satisfaction and loyalty have become a significant part for marketing research and practical management, but the explicit consumer behavior such as customers' continuous purchase or consuming is manifest and is a substantial resource for business benefits.

Thence, the purpose of this study is to investigate the cooperative manufacturer's customers and to analyze how the marketing strategy affects the customers' loyalty if reducing the overt cost per unit, information searching cost, moral hazard cost, and asset specificity cost. Suggestions will be made to adjust the direction of the marketing strategy. On the basis of the above discussion, this study is trying to develop industrial marketing strategies for the cooperative manufacturers to enhance customers' loyalty and assist in strengthening future management. In consideration of the exploration of the effect of industrial marketing strategy of cooperative manufacturers, a questionnaire was made for the customers of cooperative manufacturers in order to explore the effect on the customer loyalty with overt cost per unit (C1), information searching cost (C2), moral hazard cost (C3), and asset specificity cost (C4). In particular, Figure 1 presents the framework of quantitative research. In particular, this is based on the related academic theory to design a questionnaire survey applicable for Jia-In Industry 
Co., Ltd. to investigate their customer behavior. The overt cost per unit(C1), information searching $\operatorname{cost}(\mathrm{C} 2)$, moral hazard $\operatorname{cost}(\mathrm{C} 3)$, and asset specificity $\operatorname{cost}(\mathrm{C} 4)$ are considered in this study and the effectiveness of customer loyalty is discussed herein for making suggestion.

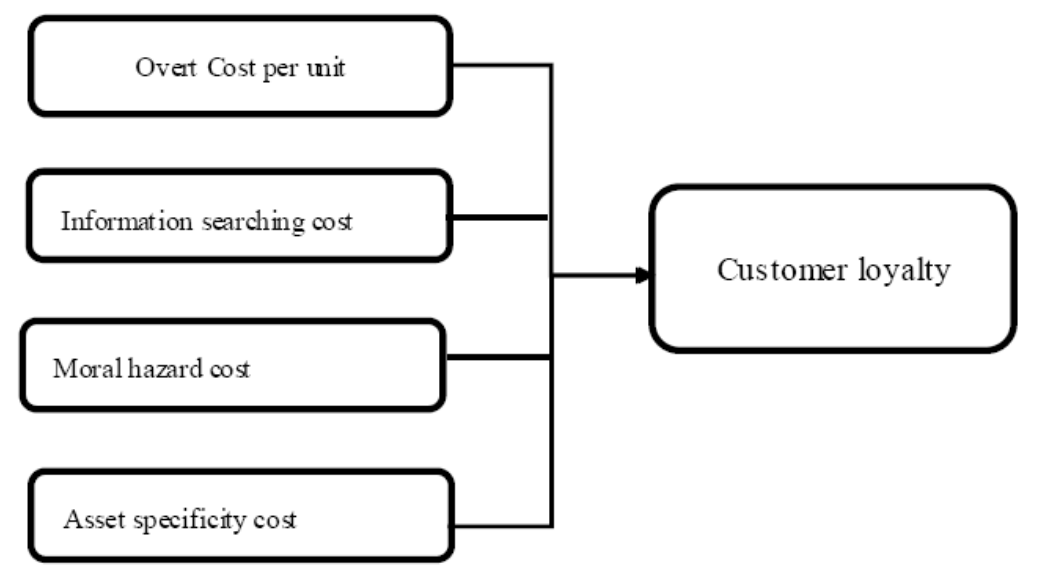

Figure1. Research framework

\section{LITERATURE REVIEW}

The purpose of this study is to investigate the customers of the cooperative manufacturer via questionnaires and also discuss how the $4 \mathrm{C}$ framework of industrial marketing strategy affects customer loyalty. Thus, the followings are some theoretical foundation for customer loyalty and $4 \mathrm{C}$ framework of industrial marketing strategy.

\subsection{Customer Loyalty}

In the past research of marketing management or customer behaviors, they focused on the analysis of developing an effective customer orientation strategy in business so as to get the positive impression or good evaluation from customers. Most of the studies conclude that customer loyalty correlates closely with the business whether it can obtain a long-term competitive advantage, profit, and sustainable management or not. (e.g., Bagram \& Khan, 2012; Hafeez \& Muhammad, 2012; Qi et al., 2012; Rai \& Medba, 2013; Rundle-Thiele, 2005; Wang \& Wu, 2012) Generally, loyalty implies a feeling or an attitude of human relationship by affection. However, the relationship between business and customer, customer loyalty encompasses a feeling or an attitude to the business. (Rai\& Medba, 2013) Rundle-Thiele (2005) thought that customer loyalty wasderived from the consumer behavior or attitude due to affection and cognition to brand or business. Qi et al. (2012) considered that the customer loyalty not only can raise the possibility of repeated purchase and positive publicity but also can bring spontaneous benefits for more company competitive advantage. (Rai\& Medba, 2013) Bagram\& Khan (2012) also proposed that customer loyalty was a key factor for promoting sales and creating sustainable competitive advantage. Customer loyalty is defined as repeated purchase in the future. Customers will return to buy for the same brand or products regardless any changes in the environment. (Rai\& Medba, 2013) In addition, Rai\& Medba (2013) defined customer loyalty as customer psychology established with long-term satisfaction and also as a reliance which accompanies with their feelings about the service provider and will contribute to the relationship among willingness, preference, purchase, and high quality.

From the viewpoint of customer orientation, customer loyalty and maintenance of competitive advantage are dispensable. (Prentice, 2013). Customer loyalty meant that the customer positive emotion displaying for the specified business reflects on their behavior in order to keep relationship in the predicable future. (Colwellet al., 2009) Yu\& Tung (2013) held that customer loyal is to keep customers' trust in business and the business needs to try hard to earn their trust and give promises. Customer loyalty is such a feeling affected by business staff, products, and services so that it is composed by intimate attitude. (Yen, 2010) Yu\& Tung (2013) also indicated that customer loyalty is a repeated purchase and a possibility which customers see themselves as business partners. Therefore, customer loyalty can be defined that customer will keep buying the products and will bring good reputation. Goncalves\& Sampaio (2012) defined customer loyalty as a normal repeated purchase or such a connection is based on their consideration on the brands or situational influence. For example, marketing strategy may change one's behavior. It seems that the loyalty represents promise, which 
means a motivation of repeated purchase. (Yaghobiet al., 2014) Wang \& Wu (2012) believed that the concept of customer loyalty is similar with relationship loyalty, that can be determined a customer's devotion to specified business, brand, product, or the whole service as well as word-of-mouth recommendation. Qi et al. (2012) Bagram \&Khan (2012) both proposed that the loyal customers will repeatedly purchase and recommend to their friends. They will give preference to some specified brand or services or will rely on them. They won't be influenced by other competitive products, so they have positive attitude, emotion, and preference on the brand, products, or services. In other words, it is that the customer is willingly to buy the same products and maintain benefit relationship among the specified companies (Bagram \& Khan, 2012). This is because an incentive brand for customer to support long time purchase without considering other brands. Moreover, Hafeez \& Muhammad (2012) considered that customer loyalty is a unique behavior results from customer and business. This means a way to predict the company's purpose in the future. Besides, the customer loyalty depends on products, services and some participation in company activities. In accordance with the above discussion, this study defines the customer loyalty as an emotional and behavioral tendency to favor Jia-In Industry Co., Ltd.'s brand, products, or services over all others.

As to factors of measuring customer loyalty, most studies viewed attitudinal loyalty and behavioral loyalty as a main element to measure customer loyaly. (e.g., Aghdai \& Khatami, 2013; Bagram \& Khan, 2012; Hafeez \& Muhammad, 2012; Rai \& Medba, 2013; Thomas, 2013; Trif, 2013) Over the past ten years, customer loyalty has always been one of the most popular issue. Many studies focused on attitudinal loyalty, behavioral loyalty or both of them. (Goncalves\& Sampaio, 2012) Attitudinal loyalty is in relation to customer preference, recommendation, and purchase intention (Yaghobi et al., 2014). On the other hand, behavioral attitude depends on customer repeated purchase by means of service provider and its reputation. (Wang\& Wu, 2012) Therefore, customer loyalty is composed with two parts: attitude and behavior. (Yu\& Tung, 2013) Bagram \& Khan (2012) thought customer loyalty originated from awareness and emotion, which means repeated purchase and be willing to keep relation with company. Aghdaie \& Khatami (2013) pointed that customer loyalty is a combination of attitudinal loyalty and behavioral loyalty and its sufficient requirements are the attitude of priority to purchase and behavior of repeated purchase. According the behavior approach, customer loyalty is such a behavior that maybe measured by purchase analysis and purchase constancy. Basing on the attitude analysis is insufficient to explain the reality of customer analysis, but it needs to consider the structure of attitude and customer performance for further illustration. In other words, the degree of customer loyalty depends on how they treat the service provider or whether to find alternative provider. Rai\& Medba (2013) insisted that customer royalty is defined as a concept of behavior mode, inclusive of repeated purchase or a degree of service, recommendation, relationship, or mixed behaviors. Trif (2013) also considered that customer loyalty has two dimensions which can quantify the customer preference for the brand and measure their brand's tendency. Behavioral loyalty means a condition that one customer repeats purchasing the same brand or services for a long time; attitudinal loyalty means an affection and promise for preferred specified brands. There were many studies to stress on the attitudinal loyalty, but customer attitude is a long-term affection for the products or the experiences and plays an import role to keep customer loyalty. If viewing repeated purchase as the loyalty, the first requirement for this is a positive attitude for brand. (Trif, 2013) Thus, attitudinal loyalty is a consideration to purchase repeatedly, maintain the relationship, and value purchase intention. On the other hands, attitudinal loyalty relies on customer belief and their support to the provider and focuses on customer's impression on business. Although customer loyalty can be presented in different way, in essence, loyalty means brand loyalty, which is not only because of repeated purchase. (Thomas, 2013 ; Trif, 2013) To put it more concretely, Behavioral loyalty can be measured by whether the customers have a willingness to recommend the specific products or services to their friends. The attitudinal loyalty can be measured by the sense of belonging or their promises to the products or services or by the degree of their brand preference. Accordingly, this study explores Jia-In Industry Co., Ltd.'s customer loyalty by means of attitudinal loyalty and behavioral loyalty.

\subsection{Industrial Marketing Strategy}

The marketing management school that used the 4Ps framework to illustrate the marketing activities views the marketing mix as a main tool to resolve the exchange problems. But Chiu (2014) held that there are four main cost that will block exchange. He also established the framework of marketing strategy, that includes 4C: Overt cost per utility (C1), Information searching cost (C2), Moral hazard 
cost (C3), and Asset specificity cost (C4). Concretely speaking, in order to promote effectiveness of marketing exchange, the core of the cooperative manufacture's marketing strategy will focus on how to effectively reduce the explicit cost (overt cost per unit) and implicit cost (information searching cost, moral hazard cost, and asset specificity cost). Chiu (2014) defined 4C as follows:

C1. Overt cost per utility

The ration of the total cost paid by the buyers for getting products or services and the total benefits from such products or services, which means $\mathrm{C} 1=$ Total cost/Total benefit.

\section{C2. Information searching cost}

This indicates a searching cost of buying products or services. In other words, because of asymmetric information, the buyer will spend more time and take cost to search some low-risk products or to check if the product or service can meet their requirement.

\section{C3. Moral hazard cost}

This means that the customer needs to bear a risk of whether the seller's claim will meet the requirement, such as function, specification, services, or other promises.

\section{C4. Asset specificity cost}

When having the relationship of exchange, the buyer can't shift to other related tangible or intangible asset. This is because the buyer needs to keep the specified asset and this will result in cost.

Chiu (2014) emphasized that the purpose of marketing is to know the factors of exchange, to solve, or to avoid problems. However, in the past time, studies focused on 4Ps for analyzing market range, but seldom viewed the $4 \mathrm{C}$ framework as a method to discuss marketing strategy and its promotion of exchange. Although $\mathrm{C} 1$ is similar to the upside down value of average benefit-cost or CostPerformance ratio, $\mathrm{C} 2$ and $\mathrm{C} 3$ connected with asymmetric information, $\mathrm{C} 4$ is close to the concept of conversion cost, and the Cost-Performance ratio, asymmetric information, and the concept of conversion cost are not new issues, it is rare to see a research exploring marketing strategy and its promotion of exchange in light of $4 \mathrm{C}$ framework. Therefore, this study aims to develop $4 \mathrm{C}$ framework of industrial marketing strategy for cooperative manufacturer in order to promote the customer loyalty and strengthen future management.

\section{RESEARCH METHOD}

This study is to enhance 4C framework of industrial marketing strategy for cooperative manufacturer to promote customer loyalty and strengthen future management. The research object is Jia-In Industry Co., Ltd., including its all team members, staff, and customers. The total capital of Jia-In Industry Co., Ltd. is NTD\$36,000,000 and 113 employees work in this company. It has dedicated to manufacture various auto strapping machine, carton stapler, pallet wrapping machines, which the company have been selling in domestic market and over 60 countries around the world. It is evident to the eye that it has good quality and good reputation. Since 1995, it started doing business in Shanghai, Shenzhen, Qingdao and Xiamen and also set up 10 more sales location for customers in mainland China for faster and more convenient services. The annual revenue of this company was approximately NTD300,000,000 and the enterprise group was around NTD120,000,000 in 2014. Moreover, Jia-In knows well about the industry environment and their customers, so all the representative samples can be collected smoothly. Purposively sampling is used to select some representative people from each management team and junior staff. Quantitative research was based on questionnaire survey contents, which was from qualitative research, and attaches importance to the questionnaire survey from cooperative manufacturer's customers in order to know how Overt cost per utility(C1), Information searching cost (C2), Moral hazard cost (C3), and Asset specificity cost(C4) affects customer loyalty. For avoiding any burden on customers, the questionnaire design must be simplified. In light of literature review, this study designed a preliminary version of questionnaire, which contains customer loyalty, Overt cost per utility(C1), Information searching cost(C2), Moral hazard cost (C3), and Asset specificity cost (C4) to know about how Jia-In Co. Ltd.'s customers evaluate customer loyalty. In addition to customer loyalty, other research-dimensioned questions will be summarized according to qualitative research. Except the personal data, all others will be evaluated by Likert scale. The personal data includes sex, marriage status, length of service, age, education and average income. According to the related research in the past, there are 4 questions in used to evaluate customer loyalty. 
This study focuses on the customers of Jia-In Industry Co. Ltd. and adopted questionnaire survey to have evidence-based data collection. Evidence-based research includes SPSS20 and AMOS 20, which are to execute statistical analysis and fsQCA. Such multivariate analysis is to realize the connectivity among different research dimension. First, Descriptive statistical analysis is to illustrate the consequence of analyzing samples. Descriptive statistical analysis for the samples is based on the basic factors such as subject's sex, marriage, length of service, age, education, experience of purchase, position, and the degree of participation to choosing providers. It will show the distribution of subjects.

FsQCA, fuzzy-set qualitative comparative analysis is a collective concept and to discuss all the sufficient requirements that may result in changes. This is also a popular research method in social area. (Chang \& Cheng, 2014, Cheng, Chang, \& Li, 2013; Ragin, 2008) Accordingly, this study is to discuss what condition leads to high customer loyalty and to view Overt cost per utility (C1), Information searching cost (C2), Moral hazard cost (C3), and Asset specificity cost(C4) as leading variable and causes to explore what kind of combination and sufficient condition will influence Jia-In industry Co. Ltd.'s customer loyalty.

\section{RESUlTS}

\subsection{Structure of Sample}

This study focuses on a questionnaire survey which is conducted via some people from each management team and junior staff, and Jia-In Industry Co., Ltd.'s customers for understanding theOvert cost per utility(C1), Information searching cost(C2), Moral hazard cost (C3), and Asset specificity $\operatorname{cost}(\mathrm{C} 4)$ have effected on customer loyalty. Table 1 showed the structure of sample of both buyer and seller. As to the sellers (management team members and junior staff), most of the subjects are females (75.0\%), unmarried people (75.0\%), age range from 26 to $45(62.5 \%)$, having length of service under 10 years $(75.0 \%)$, having bachelor degree $(62.5 \%)$, having no purchase experience $(50.0 \%)$, being an assistant (62.5\%), and having low-degree participation in decision making of choosing a provider $(75.0 \%)$. As to the buyers (customers), most of the subjects are females $(88.2 \%)$, unmarried people (94.1\%), age range from 26 to 55 (94.1\%), having length of service under 10 years (70.6\%), having bachelor degree $(94.1 \%)$, having purchase experience over 16 times $(82.4 \%)$, being an undertaker or (vice) manager (70.6\%), and having high-degree participation in decision making of choosing a provider.

Table1. Structure of sample

\begin{tabular}{|c|c|c|c|}
\hline \multicolumn{2}{|l|}{ Variable } & $\%$ for sellers & $\%$ for buyers \\
\hline \multirow[t]{2}{*}{ Gender } & Male & 25.0 & 88.2 \\
\hline & Female & 75.0 & 11.8 \\
\hline \multirow[t]{2}{*}{ Marriage } & Married & 75.0 & 94.1 \\
\hline & Single & 25.0 & 5.9 \\
\hline \multirow[t]{5}{*}{ Age } & $<26$ years old & 0.0 & 0.0 \\
\hline & $26 \sim 35$ years old & 25.0 & 35.3 \\
\hline & $36 \sim 45$ years old & 37.5 & 29.4 \\
\hline & $46 \sim 55$ years old & 12.5 & 29.4 \\
\hline & $>55$ years old & 25.0 & 5.9 \\
\hline \multirow[t]{5}{*}{ Seniority } & $<6$ years & 37.5 & 35.3 \\
\hline & $6 \sim 10$ years & 37.5 & 35.3 \\
\hline & $11 \sim 15$ years & 0.0 & 23.5 \\
\hline & 16 20 years & 12.5 & 0.0 \\
\hline & $>20$ years & 12.5 & 5.9 \\
\hline \multirow[t]{5}{*}{ Education } & Junior high school & 12.5 & 0.0 \\
\hline & High school & 0.0 & 0.0 \\
\hline & College/University & 62.5 & 94.1 \\
\hline & Master & 25.0 & 5.9 \\
\hline & Ph.D. & 0.0 & 0.0 \\
\hline \multirow[t]{5}{*}{ Experience of purchase } & Never & 50.0 & 0.0 \\
\hline & $1 \sim 5$ times & 25.0 & 5.9 \\
\hline & $6 \sim 10$ times & 0.0 & 0.0 \\
\hline & $11 \sim 15$ times & 0.0 & 11.8 \\
\hline & $>16$ times & 25.0 & 82.4 \\
\hline
\end{tabular}


Exploring the Impact of Industrial Marketing Strategy from Asymmetric Thinking in Data Analysis

\begin{tabular}{|l|l|l|l|}
\hline \hline Respondents posts & Clerk & 62.5 & 11.8 \\
\cline { 2 - 4 } & Section manager & 12.5 & 29.4 \\
\cline { 2 - 4 } & Manager & 12.5 & 41.2 \\
\cline { 2 - 4 } & General manager & 12.5 & 11.8 \\
\cline { 2 - 4 } & $>$ General manager & 0.0 & 5.9 \\
\hline \multirow{2}{*}{$\begin{array}{l}\text { Respondents level of participation in } \\
\text { decision-making to select suppliers }\end{array}$} & Very low & 75.0 & 0.0 \\
\cline { 2 - 4 } & Low & 0.0 & 0.0 \\
\cline { 2 - 4 } & Normal & 0.0 & 23.5 \\
\cline { 2 - 4 } & High & 25.0 & 58.8 \\
\cline { 2 - 4 } & Very high & 0.0 & 17.6 \\
\hline
\end{tabular}

\subsection{Results of fsQCA}

Table 2 showed that both buyer and seller have three paths to reach higher customer royalty. As to the sellers, Both solution coverage and solution consistency were more than 0.6. This study demonstrated that the industrial marketing strategy which consists of $\mathrm{C} 1, \mathrm{C} 2, \mathrm{C} 3$, and $\mathrm{C} 4$ and results in three paths can illustrate the high level customer loyalty properly. In addition, the path 1 showed that high Overt cost per utility (C1) and low Information searching cost (C2) composed a sufficient requirement of creating customer loyalty. In other words, in case customers know there was a condition of high Overt cost per utility (C1) and low Information searching cost (C2), it will result in high loyalty. The path 2 showed that high Overt cost per utility (C1) and high Moral hazard cost (C3) will lead to higher loyalty. Finally, the path 3 showed that having high Overt cost per utility (C1), high Information searching cost (C2), and high Moral hazard cost (C3) will also lead to higher loyalty.

As to the buyer, both solution coverage and solution consistency were more than 0.6. It meant that all the three paths can illustrate the high level customer loyalty properly. The path 1 showed that high Overt cost per utility (C1) and high Moral hazard cost (C3) will lead to higher loyalty. The path 2 showed that low Information searching cost (C2), high Moral hazard cost (C3), and high Asset specificity cost (C4) will lead to higher loyalty. The path 3 showed that if all the Information searching cost (C2), Moral hazard cost (C3), and Asset specificity cost (C4) were high, the customer will have higher loyalty. (See Table 2)

Table2. The causal configurations for high customer loyalty

\begin{tabular}{|c|c|c|c|c|c|c|c|c|c|c|}
\hline & Path & C1 & $\mathbf{C 2}$ & $\mathbf{C 3}$ & C4 & $\begin{array}{l}\text { Raw } \\
\text { coverage }\end{array}$ & $\begin{array}{l}\text { Unique } \\
\text { coverage }\end{array}$ & Consistency & $\begin{array}{l}\text { Solution } \\
\text { coverage }\end{array}$ & $\begin{array}{l}\text { Solution } \\
\text { consistency }\end{array}$ \\
\hline \multirow[t]{3}{*}{ Sellers } & $1 \mathrm{a}$ & $\bullet$ & 0 & & & .656 & .098 & 1.000 & \multirow[t]{3}{*}{.823} & \multirow[t]{3}{*}{1.000} \\
\hline & $2 \mathrm{a}$ & $\bullet$ & & $\bullet$ & & .705 & .124 & 1.000 & & \\
\hline & $3 a$ & $\bullet$ & $\bullet$ & $\bullet$ & & .432 & .020 & 1.000 & & \\
\hline \multirow[t]{3}{*}{ Buyers } & $1 \mathrm{~b}$ & $\bullet$ & & $\bullet$ & & .770 & .163 & .996 & \multirow[t]{3}{*}{.831} & \multirow[t]{3}{*}{.996} \\
\hline & $2 b$ & & 0 & $\bullet$ & $\bullet$ & .619 & .020 & 1.000 & & \\
\hline & $3 b$ & $\bullet$ & $\bullet$ & & $\bullet$ & .428 & .041 & 1.000 & & \\
\hline
\end{tabular}

Notes: $C 1$ indicates overt cost per utility, $C 2$ indicates information searching cost, $C 3$ indicates moral hazard cost, and C4 indicates asset specificity cost.

\section{REFERENCES}

Aghdaie, S.F.A. \& Khatami, F. (2013). A study of the customer shopping behavior and effective factors on building up customer loyalty. International Review of Management and Business Research, 2 (4), 1011-1023.

Armstrong, G. \& Kotler, P. (2014). Marketing: An Introduction, 12th ed. Prentice-Hall, N.J.

Bagram, D.M.M.M. \& Khan, S. (2012). Attaining customer loyalty! The role of consumer attitude and consumer behavior. International Review of Management and Business Research, 1 (1), 1-8.

Chang, M.L. \& Cheng, C.F. (2014). How balance theory explains high-tech professionals' solutions of enhancing job satisfaction. Journal of Business Research, 67 (9), 2008-2018.

Cheng, C.F., Chang, M.L., \& Li, C.S. (2013). Configural paths to successful product innovation. Journal of Business Research, 66 (12), 2561-2573.

Chiu, C.S. (2014). Strategic marketing analysis: Framework \& Practical Application. BEST-WISE PUBLISHING CO., LTD.

Chou, P.F. \& Lu, C.S. (2009). Assessing service quality, switching costs and customer loyalty in home-delivery services in Taiwan. Transport Reviews, 29 (6), $741-758$. 
Colwell, S., Hogarth-Scott, S., Jiang, D., \& Joshi, A. (2009). Effects of organizational and serviceperson orientation on customer loyalty. Management Decision,47 (10), 1489-1513.

García, J.A.M. \& Caro, L.M. (2009). Understanding customer loyalty through system dynamics:The case of a public sports service in Spain. Management Decision, 47 (1), 151-172.

Goncalves, H.M. \& Sampaio, P. (2012). The customer satisfaction-customer loyalty relationship. Management Decision,50 (9), 1509-1526.

Goyal-Wasan, \& P. Tripathi, G. (2014). Revisiting social marketing mix: A socio-cultural perspective. Journal of Services Research, 14 (2), 127-144.

Hafeez, S. \& Muhammad, B. (2012). The impact of service quality, customer satisfaction and loyalty programs on customer's loyalty: Evidence from banking sector of Pakistan. International Journal of Business and Social Science, 3 (16), 200-209.

Hansses, D.M., Pauwels, K.H., Srinivasan, S., Vanhuele, M., \& Yildirim, G. (2014). Consumer attitude metrics for guiding marketing mix decisions. Marketing Science, 33 (4), 534-550.

Helm, R. \& Gritsch, S. (2014). Examining the influence of uncertainty on marketing mix strategy elements in emerging business to business export-markets. International Business Review, 23 (2), 418-428.

Huang, R. \&Sarigöllü, E. (2012). How brand awareness relates to market outcome, brand equity, and the marketing mix. Journal of Business Research, 65 (1), 92-99.

Liu, D. \& Viswanathan, S. (2014). Information asymmetry and hybrid advertising. Journal of Marketing Research, 51 (5), 609-624.

Noori, B. (2015). Developing a CBR system for marketing mix planning and weighting method selection using fuzzy AHP. Applied Artificial Intelligence: An International Journal, 29 (1), $1-32$.

Prentice, C. (2013). Service quality perceptions and customer loyalty in casinos. International Journal of Contemporary Hospitality Management, 25 (1), 49-64.

Qi, J.Y., Zhou, Y.P., Chen, W.J., \& Qu, Q.X. (2012). Are customer satisfaction and customer loyalty drivers of customer lifetime value in mobile data services: A comparative cross-country study. Information Technology and Management, 13 (4), 281-296.

Ragin, C. C. (2008). User's Guide to Fuzzy-Set/Qualitative Comparative Analysis. Available online at: www.fsqca.com.

Rai, A.K. \& Medba, S. (2013). The antecedents of customer loyalty: An empirical investigation in life insurance context. Journal of Competitive, 5 (2), 139-163.

Rundle-Thiele, S. (2005). Loyalty: An empirical exploration of theoretical structure in two service markets. University of SouthAustralia, Doctoral Dissertation. Adelaide, Australia.

Thomas, S. (2013). Linking customer loyalty to customer satisfaction and store image: A structural model for retail stores. Decision, 40(1-2), 15-25.

Trif, S.M. (2013). The influence of overall satisfaction and trust on customer loyalty. Management \& Marketing, 8 (1), 109-128.

Wang, C.Y. \& Wu, L.W. (2012). Customer loyalty and the role of relationship length. Managing Service Quality, 22 (1), 58-74.

Yaghobi, S., Ahmadi, F., \& Shojaee, A. (2014). Survey effects of relationship marketing tactics on shopping behavior in stores Kurdistan province. Interdisciplinary Journal of Contemporary Research in Business, 5 (12), 63-74.

Yen, Y.S. (2010). Can perceived risks affect the relationship of switching costs and customer loyalty in e-commerce? Internet Research,20 (2), 210-224.

$\mathrm{Yu}, \mathrm{T} . \mathrm{W} . \&$ Tung, F.C. (2013). Investigating effects of relationship marketing types in life insurers in Taiwan. Managing Service Quality,23 (2), 111-130.

Zhang, X., Han, X., Liu, X., Liu, R., \& Leng, J. (2015). The pricing of product and value-added service under information asymmetry: a product life cycle perspective. International Journal of Production Research, 53 (1), 25-40. 


\section{AUTHORS' BIOGRAPHY}

Cheng-Feng Cheng, is the associate professor and Chair of Department of International Business and associate professor of Department of Business Administration in Asia University, Taiwan. He received his Ph.D. degree in Management from National Cheng Kung University, Taiwan. His research interests are strategic management, marketing management, and consumer behavior. He has participated in some international conferences and published some papers in Technovation, Journal of Business Research, Industrial Marketing Management, Applied Economics Letters, Journal of Computer Information Systems, and elsewhere.

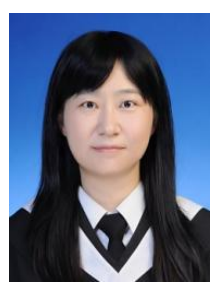

Li-Chuan Hsieh, is the executive of Jia-In Industry Co., Ltd. She received her MBA degree from Department of International Business in Asia University, Taiwan. 